\title{
STRATEGI PENINGKATAN KOMPETENSI GURU DALAM PROSES BELAJAR MENGAJAR
}

\author{
Monica Febriana Suwandi, Carolina Lita Permatasari \\ Universitas Kristen Satya Wacana, Indonesia \\ 162015003@student.uksw.edu,carolina.permatasari@uksw.edu
}

\begin{abstract}
Abstrak: Penelitian ini bertujuan untuk mengidentifikasikan nilai-nilai strategis, menganalisis lingkungan strategis yang mempengaruhi, dan merumuskan strategi yang dapat berfungsi secara efektif dan efisien dalam peningkatan kompetensi guru. Fokus penelitian ini mengenai strategi peningkatan kompetensi guru, sehingga menggunakan analisis SWOT sebagai instrumen utama dalam mengukur lingkungan untuk memperoleh strategi yang diperlukan dalam proses penyusunan perencanaan peningkatan kompetensi guru. Informan yang digunakan dalam pengumpulan data yaitu kepala sekolah, guru, siswa, pihak Dinas Pendidikan, yayasan, orang tua siswa, dan stakeholder terkait. Penentuan informan tersebut menggunakan teknik snowballing. Proses analisis yang dilakukan dengan identifikasi lingkungan internal dan eksternal untuk menilai kelemahan, kekuatan, peluang, dan ancaman dalam peningkatan kompetensi guru. Kemudian menganalisis strategi berdasarkan data-data yang ditemukan, baik mengenai kelemahan, kekuatan, peluang, maupun ancaman yang dimiliki ke dalam analisis SWOT, sehingga menghasilkan strategi SO, WO, ST, dan WT. Langkah selanjutnya yaitu mengidentifikasi isu-isu strategis berdasarkan hasil dari analisis SWOT dengan menggukanan tes litmus untuk menentukan alternatif-alternatif strategi, sehingga diperoleh penetapan strategi peningkatan kompetensi guru sebagai usaha intensifikasi pelaksanaan program pengembangan kompetensi guru.
\end{abstract}

Kata kunci: Manajemen Strategi, Identifikasi Lingkungan, Analisis SWOT, Tes Litmus

\section{STRATEGY OF TEACHER COMPETENCY IMPROVEMENT}

\begin{abstract}
This study aims to identify strategic values, analyze the influencing strategic environment, and formulate strategies that can effectively and efficiently increase teacher competence. This research focuses on strategies for improving teacher competence. It uses SWOT analysis to measure the environment to obtain the system needed in planning teacher competency improvement. The informants used in data collection were school principals, teachers, students, the Education Department, foundations, parents of students, and related stakeholders. Determination of the informants using snowballing techniques. The analysis process is carried out by identifying the internal and external environment to assess weaknesses, strengths, opportunities, and threats in increasing teacher competence. Then analyze the strategy based on the data found, both regarding the flaws, strengths, opportunities, and threats that are owned into the SWOT analysis, to produce SO, WO, ST, and WT strategies. The next step is to identify strategic issues based on the SWOT analysis results by using a litmus test to determine strategic alternatives to obtain a method for improving teacher competence to intensify the implementation of teacher competency development programs.
\end{abstract}

Keywords: Strategic Management, Environmental Identification, SWOT Analysis, Litmus Test

\section{PENDAHULUAN}

Guru merupakan komponen utama dalam proses pendidikan. Sebagai seorang pendidik, guru wajib memiliki kualifikasi akademik, kompetensi, sertifikat pendidik, sehat jasmani dan rohani, serta memiliki kemampuan untuk mewujudkan tujuan pendidikan nasional (UU Guru Dan Dosen, 2005)Kompetensi yang dimiliki seorang guru itu meliputi kompetensi pedagogik, kompetensi kepribadian, kompetensi sosial, kompetensi profesional melalui pendidikan profesi. 
Profesionalisme menurut (Schein, 2004) merupakan bekerja sepenuhnya (full time) berbeda dengan amatir yang sambilan. Mempunyai motivasi yang kuat. Mempunyai pengetahuan (science) dan ketrampilan (skill), membuat keputusan atas nama klien (pemberi tugas), berorientasi pada pelayanan (service orientation). Penjelasan tersebut dapat diartikan bahwa profesionalisme merupakan pekerjaan yang harus memiliki skill yang bagus, pengetahuan yang bagus dan berfokus pada pelayanan. Itu sebabnya harus dilakukan oleh orang yang memiliki pengetahuan yang sangat bagus guna menyalurkan pengetahuan yang dimiliki dapat disalurkan kepada seseorang yang lain.

Profesionalisme adalah sebutan yang mengacu kepada sikap mental alam bentuk komitmen anggota suatu profesi untuk senantiasa mewujudkan dan meningkatkan profesionalnya (Suyanto, 2013) Guru dengan profesionalismenya yang tinggi akan terlihat dalam bentuk sikap mental dan komitmennya terhadap peningkatan kualitas profesionalnya melalui berbagai cara dan strategi karena sikap yang baik akan memunculkan hal yang baik pula untuk melayani siswa. Kompetensi profesional merupakan penguasaan materi pembelajaran secara meluas yang harus dikuasai guru terkait dengan penguasaan materi kurikulum mata pelajaran di sekolah (Suyanto dkk, 2013). Dari kutipan tersebut menjelaskan bahwa kompetensi profesional guru harus menguasai tentang penguasaan materi kurikulum mata pelajaran yang ada di sekolah. Kemudian menerapkannya dalam proses belajar mengajar di kelas sesuai dengan rancangan pelaksanaan pembelajaran.

Kompetensi pedagogik adalah kompetensi tentang bagaimana sebaiknya pendidikan dilaksanakan sesuai kaidah mendidik, tentang sistem pendidikan, tujuan pendidikan, metode dan media pendidikan, sarana dan prasarana pendidikan, dan materi pendidikan (Surya, Mohammad, 2010). Menurut pengertian di atas bahwa kompetensi pedagogik adalah kompetensi dimana guru harus menguasai materi pelajaran yang akan di sampaikan sesuai dengan perencanaan mengajar sehingga dapat mengendalikan proses belajar mengajar yang berlangsung.

Kompetensi sosial adalah kemampuan guru dalam menempatkan dirinya sebagai bagian dari masyarakat untuk berkomunikasi dan berinteraksi secara efektif dan efisien dengan peserta didik, sesama pendidik, tenaga kependidikan, orangtua/wali murid dan masyarakat sekitar (Rifma., 2006). Dari uraian tersebut jelas bahwa kompetensi sosial terhadap guru mencakup luas. Terbukti seorang guru tidak hanya bisa memaparkan materi yang bagus namun, dituntut untuk memiliki akhlak yang bagus di lingkungan sekolah. Tidak hanya sebagai mentor dalam pendidikan namun komunikasi dengan pihak internal maupun eksternal.

Kompetensi kepribadian adalah seorang guru ideal akan menunjukkan kepribadian yang mantap, stabil, dan dewasa sehingga dapat menjadi teladan bagi peserta didik dan lingkungan sekitarnya (Rifma, 2016: 26). Penjelasan dari kutipan tersebut bahwa kompetensi kepribadian dan sosial tidak jauh berbeda dengan adanya keterkaitan antara kompetensi tersebut. Bahwa, kepribadian yang baik maka sosialnya akan mengikuti. Guru yang memiliki kepribadian yang bisa membawa dirinya dalam hal positif tentu juga sosial dirinya akan mengikuti.

Sesuai PP No. 19 Tahun 2005 tentang Standar Nasioanal Pendidikan pasal 28 (3) menyatakan bahwa kompetensi yang harus dimiliki oleh seorang guru sebagai agen pembelajaran adalah sebagai berikut: (1) Kompetensi pedagogik adalah kemampuan mengelola pembelajaran peserta didik meliputi pemahaman terhadap peserta didik, perancangan dan pelaksanaan pembelajaran, evaluasi hasil belajar, dan pengembangan peserta didik untuk mengaktualisasikan berbagai kompetensi yang dimilikinya. (2) Kompetensi kepribadian adalah kemampuan kepribadian yang mantap, stabil, dewasa, arif dan berwibawa, menjadi teladan bagi peserta didik, danberakhlak mulia. (3) Kompetensi profesional adalah kemampuan penguasaan materi pembelajaran secara luas dan mendalam yang memungkinkannya membimbing peserta didik memenuhi standar kompetensi yang ditetapkan. (4) Kompetensi sosial adalah kemampuan pendidik sebagai bagian dari masyarakat untuk berkomunikasi dan bergaul secara efektif dengan peserta didik, sesama pendidik, tenaga kependidikan, orang tua/wali peserta didik, dan masyarakat sekitar. Tanpa mengabaikan kompetensi yang lainnya, kompetensi profesional 
merupakan kompetensi yang harus dimiliki oleh guru yang profesional. Kompetensi tersebut harus dikembangkan dalam rangka mencapai tujuan pembelajaran di sekolah. Kompetensi profesional dipandang penting untuk dikembangkan oleh para guru karena kompetensi profesional mencakup kemampuan guru dalam penguasaan terhadap materi pelajaran dan kemampuan guru dalam pengelolaan pembelajaran.

Upaya yang harus dilakukan pemerintah bukan hanya fokus pada ke empat kompetensi itu. Namun harus ada kompetensi yang lain guna mengembangkan kompetensi-kompetensi yang dimiliki oleh setiap guru. Pemerintah harus mengupayakan terciptanya kompetensi yang baru untuk mengasah kemampuan guru secara teknologi dan teacherpreunership. Guru yang mampu mengendalikan teknologi yang baik maka dapat mengembangkan teknologi dalam memberi pelajaran di kelas agar dapat menemukan metode pembelajaran yang baru. Tidak hanya pandai dalam teknologi namun guru juga harus memiliki jiwa teacherpreunership guna meningkatkan kompetensi yang sudah dimiliki. Teacherpreunership adalah guru yang mempunya jiwa kreatif dalam berwirausaha. Bukan hanya berjiwa wirausaha namun dapat memunculkan produktivitas dalam kompetensi yang dimilikinya. Berawal dari jiwa yang kreatif akan menimbulkan pembelajaran yang baru. Sehingga guru dapat mempunyai kemampuan pendekatan dengan metode dan strategi dengan mengembangkan kreativitasnya.

Kreativitas merupakan kemampuan untuk mengembangkan daya cipta perihal berkreasi. Dalam pendidikan kreatifitas sangatlah perlu sebagai seorang pendidik memberikan materi pelajaran kepada anak didiknya. Namun kreatif bukan haya menciptakan sesuatu, akan tetapi juga berkaitan dengan kedisiplinan. Guru yang bijak dalam menjalankan profesinya akan disiplin dengan aktivitas yang dijalankan di dalam lembaga pendidikan.

Namun, dari penjelasan 4 kompetensi tersebut sampai saat ini belum terlaksana dengan baik.

"Banyak guru yang masih ogah-ogahan untuk mencari wawasan bahan ajar yang akan disampaikan di kelas. Terus mengaplikasikan teknologi juga kurang di sekolah ini, kalau buat ppt bisa mbak tapi kalau mengaplikasikan materi ke link agak susah". (Menurut Suwasono,. wawancara tanggal 13 Maret 2019).

Berdasarkan yang dikemukan beliau bahwa sekolah ini sangat butuh untuk guru dapat memahami arti penting teknologi di era sekarang. Fenomena yang terjadi bahwa di sekolah ini guru-guru kurang mampu untuk menguasai teknologi.

"Bahkan untuk mengadakan pelatihan saja pihak sekolah gak punya dana. Karena dana yang ada dialokasikan untuk kegiatan sekolah saja". (Menurut Suwasono selaku Kepala Sekolah SMP Kristen Satya Wacana Salatiga).

Setiap sekolah pasti mempunyai program kerja yang diadakan di sekolah. Namun, berdasarkan pengamatan, masih belum terwujud hanya sebatas rencana tapi dalam pelaksanaanya belum terpenuhi.

"Tapi, saya punya plan ya gitu kalau semua tempat dan ruangan sekitar sekolah ini memakai jaringan internet. Karena sudah lama anak-anak gak pake HP untuk mengakses informasi tentang pengetahuan. Justru malah sekolah favorit kok gurunya katrok teknologi“. (Tutur Suwasono pada wawancara tanggal 13 Maret 2019).

Berdasarkan penjelasan yang dikatakan oleh kepala sekolah bahwa permasalahan yang ada di SMP Kristen Satya Wacana Salatiga adalah penggunaan teknologi dalam proses belajar mengajar. Karena sarana dan prasarana yang kurang memadai sehingga kegiatan di sekolah belum optimal 
dalam peningkatan kompetensi guru. Permasalahan yang timbul di sekolah ini disebabkan karena tidak pernah menyelenggarakan strategi peningkatan yang berkaitan dengan kompetensi profesional.

Dari pihak dinas menyelenggarakan workshop, seminar tetapi tidak berkaitan dengan kompetensi guru untuk meningkatkan penggunaan teknologi. Peraturan baru juga masuk bahwa pelajaran teknologi infomatika dan teknologi sudah ditiadakan. Seharusnya guru mata pelajaran tersebut mengajar pelajaran itu, namun beralih ke pelajaran yang lain. Padahal, sekolah memiliki 32 komputer di laboratorium dari pemerintah. Maka dari itu pihak sekolah mengadakan ekstrakulikuler komputer guna mengasah anak dalam mengetahui teknologi di zaman sekarang. Harapan sekolah juga ingin para pendidik dan anak didik beserta staf mengerti akan penggunaan teknologi, hanya keterbatasan dalam anggaran untuk menyelenggarakan pelatihan atau workshop yang berkaitan dengan teknologi.

SMP Kristen Satya Wacana Salatiga tergolong SMP yang popular, oleh sebab itu sekolah harus mempunyai strategi guna meningkatkan kompetensi guru. Sekolah akan unggul jika memiliki pengajar yang kompeten dan berjiwa kreatif dalam mendidik siswa di lembaga pendidikan karena menurut pengamatan dari penulis bahwa di SMP Kristen Satya Wacana Salatiga tidak semuanya guru dapat mengaplikasikan metode pembelajaran dengan menggunakan teknologi. Seiring berkembangnya zaman akan lebih baik jika seorang guru berkompeten juga dalam hal teknologi dalam memberikan materi pembelajaran (Standar Nasional Pendidikan, 2005).

Penelitian Mustofa (2012) mengenai upaya pengembangan profesionalisme guru mengatakan bahwa seorang guru harus mempunyai standar profesi yang bagus. Sehingga dapat dikatakan bahwa profesionalisme seorang guru akan terbukti jika guru sudah memliki standar kompetensi profesionalisme yang bagus tidak menutup kemungkinan bahwa proses belajar mengajar dapat berjalan dengan baik. Sedangkan penelitian (Nurhayati, 2018) mengatakan bahwa strategi peningkatan produktivitas itu diperlukan karena adanya daya saing di jaman sekarang. Begitu banyak produk yang sama namun berbeda dalam meningkatkan produktifitasnya. Faktor yang menghambatnya bisa karena sumber daya alam dan sumber daya manusia yang terbatas. (Saifulloh et al., 2012) mengungkapkan strategi peningkatan mutu pendidikan adalah bahwa perlu adanya pelatihan seperti seminar workshop, guna untuk memberikan inovasi-inovasi terhadap guru untuk mengasah profesionalnya sebagai tenaga pendidik melalui cara pendekatan di sekolah dan cara mengajar yang menyenangkan. Senada dengan (Moleong, 2007)dalam mengungkapkan strategi manajemen peningkatan mutu pendidikan, bahwa proses pembelajaran pada pendidikan haruslah fleksibel, bervariasi dan menyenangkan karena dengan itu proses belajar mengajar akan dikatakan berhasil sesuai dengan standart lingkup pendidikan.

Pendapat para ahli mengenai manajemen strategi dikemukan dengan berbagai pandangan. Menurut (Siagian, 2005) manajemen strategi adalah serangkaian keputusan dan tindakan mendasar yang dibuat oleh manajemen puncak dan diimplementasikan oleh seluruh jajaran suatu organisasi dalam rangka pencapaian organisasi tersebut. Menurut (David, n.d., 2009) manajemen strategis terdiri dari tiga tahap : perumusan strategi, mencakup pengembangan visi dan misi, identifikasi peluang dan ancaman eksternal suatu organisasi, kesadaran akan kekuatan dan kelemahan internal, penetapan tujuan jangka panjang, pencarian strategi alternatif, dan pemilihan strategi tertentu untuk mencapai tujuan; penerapan strategi, untuk menetapkan tujuan tahunan, membuat kebijakan, memotivasi karyawan, dan mengalokasikan sumber daya. Penerapan strategi mencakup pengembangan budaya yang suportif pada strategi, penciptaan struktur organisasional yang efektif, pengerahan ulang upaya-upaya pemasaran, penyiapan anggaran, pengembangan serta pemanfaatan sistem informasi, dan pengaitan kompensasi karyawan dengan kinerja organisasi; penilaian strategi, mencakup peninjauan ulang faktor-faktor eksternal dan internal 
yang menjadi landasan bagi strategi saat ini, pengukuran kinerja, dan pengambilan langkah korektif

Menurut (Tangkilisan, 2003), perencanan strategis adalah suatu sistem dimana para manajer mengambil keputusan, mengimplementasikan, dan mengkontrol keputusan penting tersebut. (Rangkuti, 2005) memberikan kesimpulan mengenai perencanaan strategis melalui tiga tahap analisis, yaitu : tahap pengumpulan data, tahap analisis, dan tahap pengambilan keputusan. Dalam penyusunan rencana strategis harus sudah jelas nilai-nilai strategis yang dimiliki oleh daerah tersebut. Termasuk dalam mengidentifikasi nilai-nilai strategis yang dimiliki oleh SMP Kristen Satya Wacana Salatiga. Pada kategori mengidentifikasi nilai-nilai strategis setiap sekolah berbeda-beda dalam menghadapi strategi yang akan ditingkatkan.

\section{METODE}

Penelitian ini menggunakan tipe penelitian deskriptif dengan pendekatan kualitatif. Penelitian ini lebih menitikberatkan pada fokus mengenai strategi peningkatan kompetensi profesionalisme guru dalam proses belajar mengajar di SMP Kristen Satya Wacana Salatiga. Informan dalam penelitian ini menggunakan tiga pilar yaitu pihak kepala sekolah, guru/staff dan siswa di SMP Kristen Satya Wacana. Informan ini dianggap sebagai orang-orang kunci. Dalam penelitian ini yang menjadi instrumen penelitian yang utama adalah peneliti itu sendiri. Sedangkan instrumen pendukung lainnya ialah alat-alat pendukung seperti interview guide yang merupakan panduan peneliti dalam melakukan wawancara dengan narasumber, analisis SWOT yang merupakan alat formulasi strategi guna melakukan identifikasi berbagai faktor secara sistematis untuk merumuskan strategi organisasi, tape recorder yang merupakan alat perekam wawancara, serta alat-alat pendukung lain yang digunakan oleh peneliti, baik dalam pengumpulan data, pengolahan data, maupun penyimpanan data.

Sumber data dalam penelitian ini diperoleh langsung dari data sebagai berikut data primer (data diperoleh dari hasil wawancara langsung kepada informan) dan data sekunder (diperoleh dari studi pustaka atau bahan informasi lain yang berhubungan dengan masalah yang akan diteliti, baik dari tinjauan pustaka maupun dokumen-dokumen). Menurut Lofland \& Lofland, sumber data primer dalam penelitian kualitatif adalah kata-kata dan tindakan, selebihnya adalah data tambahan seperti dokumen dan lain-lain (Moleong, 2007). Ditinjau dari teknik pengumpulannya, data diperoleh melalui : Dokumentasi, Interview / Wawancara., Observasi, dan Studi Pustaka. Adapun langkah-langkah analisis data dalam penelitian ini yaitu : 1) Mengidentifikasi tujuan yang ingin dicapai berdasarkan visi dan misi Dinas Pendidikan dan SMP Kristen Satya Wacana. Melakukan analisis kondisi awal organisasi, yaitu kondisi SMP Kristen Satya Wacana Salatiga yang meliputi lingkungan internal (SDM, anggaran, budaya, dan struktur organisasi, sarana dan prasarana) dan lingkungan eksternal (faktor geografis, ekonomi, sosial budaya, teknologi, dan dukungan stakeholder, dukungan masyarakat, dukungan dinas, dukungan gereja, sekolah pesaing); 2) Analisis SWOT, yaitu dengan menganalisis data sekunder maupun data primer untuk menilai lingkungan eksternal berupa peluang dan ancaman dengan memantau berbagai kecenderungan politik, ekonomi, sosial budaya dan teknologi. Menilai lingkungan internal berupa kekuatan dan kelemahan dengan memantau sumber daya, strategi yang dilakukan, dan hasil kinerja di SMP Kristen Satya Wacana Salatiga; 3)Mengidentifikasi isu-isu strategis dalam peningkatan kompetensi profesionalisme guru; dan 4)Merumuskan strategi guna tercapainya tujuan yang telah ditentukan. 


\section{Gambar 1}

\section{Diagram Analisis SWOT}

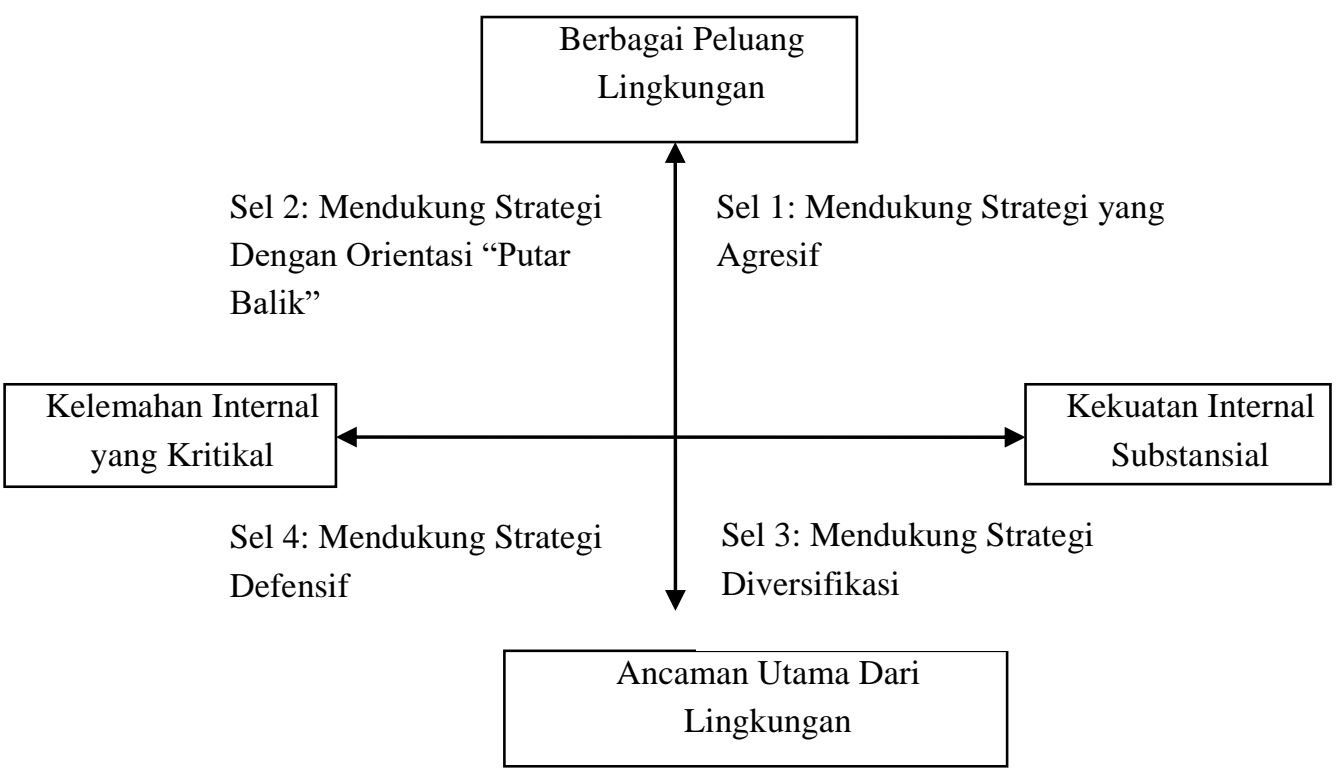

Gambar 1 Diagram Analisis SWOT

Keterangan dari diagram di atas :

Kuadran 1: Kondisi dalam kuadran ini sangat menguntungkan. Karena, sekolah tersebut memiliki peluang dan kekuatan sehingga dapat memanfaatkan peluang yang ada. Strategi yang harus dilakukan dalam keadaan seperti ini adalah mendukung kebijakan pertumbuhan yang agresif (Growth oriented strategy)

Kuadran 2: Walaupun dari dalam ada ancaman, akan tetapi sekolah masih memiliki kekuatan secara internal. Strategi yang harus diterapkan adalah menggunakan kekuatan untuk memperkuat dalam menghadapi ancaman sebagai peluang jangka panjang dengan cara strategi diversifikasi.

Kuadran 3: Sekolah menghadapi peluang yang dapat dimanfaatkan, tetapi dilain pihak sekolah juga mengahapi beberapa kendala/kelemahan internal.

Kuadran 4: Ini merupakan keadaan yang sangat tidak baik, sekolah menghadapi berbagai ancaman dan kelemahan internal. 
Tabel 1. Diagram Matriks SWOT

\begin{tabular}{|c|c|c|}
\hline EFAS & $\begin{array}{c}\text { STRENGTHS (S) } \\
\text { Tentukan 5-10 faktor } \\
\text { faktor-faktor } \\
\text { kelemahan internal }\end{array}$ & $\begin{array}{c}\text { WEAKNESS (W) } \\
\text { Tentukan 5-10 kekuatan } \\
\text { internal }\end{array}$ \\
\hline $\begin{array}{l}\text { OPPORTUNIES (O) } \\
\quad \text { Tentukan 5-10 } \\
\text { Faktor peluang } \\
\text { Eksternal }\end{array}$ & \begin{tabular}{l}
\multicolumn{1}{c}{ STRATEGI SO } \\
Ciptakan strategi yang \\
menggunakan kekuatan \\
untuk memanfaatkan \\
peluang
\end{tabular} & $\begin{array}{l}\text { STRATEGI WO } \\
\text { Ciptakan strategi yang } \\
\text { meminimalkan } \\
\text { kelemahan } \\
\text { untuk memanfaatkan } \\
\text { peluang }\end{array}$ \\
\hline $\begin{array}{l}\text { TREATHS (T) } \\
\text { Tentukan 5-10 } \\
\text { Faktor ancaman } \\
\text { Eksternal }\end{array}$ & \begin{tabular}{l}
\multicolumn{1}{c}{ STRATEGI ST } \\
Ciptakan strategi yang \\
menggunakan kekuatan \\
untuk mengatasi ancaman
\end{tabular} & $\begin{array}{l}\text { STRATEGI WT } \\
\text { Ciptakan strategi yang } \\
\text { meminimalkan } \\
\text { kelemahan } \\
\text { dan menghindari } \\
\text { ancaman }\end{array}$ \\
\hline
\end{tabular}

Sumber : Analisis SWOT Membedah Suatu Kasus, Freddy Rangkuti (2005)

Keterangan dari diagram matriks di atas adalah :

- Strategi SO (strength-opportunity) adalah strategi yang dilakukan perusahaan dengan memanfaatkan atau mengoptimalkan kekuatan yang dimiliki/ strength (S) untuk memanfaatkan berbagai peluang/ opportunity (O).

- Strategi WO (weaknesses-opportunity) adalah strategi yang digunakan perusahaan dalam mengurangi kelemahan/ weaknesses (W) yang ada untuk memanfaatkan berbagai peluang/ opportunity $(\mathrm{O})$.

- Strategi ST (strength-threats) adalah strategi yang digunakan perusahaan dalam mengoptimalkan kekuatan/ strength (S) untuk mengurangi ancaman/ threats $(\mathrm{T})$ yang mungkin terjadi.

Strategi WT (weaknesses-threats) adalah strategi yang digunakan untuk mengurangi kelemahan/ weaknesses (W) dalam rangka menghindari ancaman/ threats $(\mathrm{T})$.

Secara garis besar analisis lingkungan strategis peningkatan kompetensi profesional guru diuraikan sebagai berikut: 1) Analisis Lingkungan Internal adalah visi misi SMP Kristen Satya Wacana Salatiga, SDM, kondisi sekolah, anggaran, infrastruktur, budaya organisasi; 2) Analisis Lingkungan Eksternal adalah dukungan dinas, dukungan gereja, dukungan Masyarakat, dukungan stakeholder, dukungan yayasan, faktor teknologi, faktor ekonomi, faktor geografis, faktor sosial dan budaya, dan sekolah pesaing. Dari beberapa isu yang telah teridentifikasi, untuk mengetahui isu-isu yang benar-benar strategis, akan dilakukan uji litmus. Menurut Bryson (Tangkilisan, 2003: 64) hal-hal yang akan dinyatakan pada litmus test dapat dilihat pada tabel sebagai berikut : 
Tabel 2. Model Tes Litmus

\begin{tabular}{|c|c|c|c|}
\hline \multirow{2}{*}{ Pertanyaan Uji } & \multicolumn{3}{|c|}{ Operasional Strategi } \\
\hline & $(1)$ & $(2)$ & $(3)$ \\
\hline $\begin{array}{l}\text { Kapan peluang/tantangan isu anda } \\
\text { hadapi }\end{array}$ & Sekarang & Tahun depan & $\begin{array}{l}\text { Lebih dari } 2 \\
\text { tahun }\end{array}$ \\
\hline Seberapa luas pengaruh isu ini & Sedikit & Sedang & Luas \\
\hline Seberapa besar biaya yang diperlukan & $\begin{array}{c}10 \% \text { dari } \\
\text { kemampuan }\end{array}$ & $\begin{array}{c}25 \% \text { dari } \\
\text { kemampuan }\end{array}$ & Diatas $25 \%$ \\
\hline \multicolumn{4}{|l|}{$\begin{array}{l}\text { Apakah pilihan isu memerlukan hal } \\
\text { berikut : }\end{array}$} \\
\hline $\begin{array}{l}\text { a. Pengembangan pelayanan } \\
\text { baru }\end{array}$ & Tidak & & $\mathrm{Ya}$ \\
\hline $\begin{array}{l}\text { b. Penyesuaian terhadap } \\
\text { peraturan perundangan }\end{array}$ & Tidak & & $\mathrm{Ya}$ \\
\hline $\begin{array}{l}\text { c. Penambahan terhadap fasilitas } \\
\text { utama }\end{array}$ & Tidak & & $\mathrm{Ya}$ \\
\hline $\begin{array}{l}\text { d. Penambahan tenaga } \\
\text { kerja/staf/karyawan }\end{array}$ & Tidak & & $\mathrm{Ya}$ \\
\hline Pendekatan terbaik bagi pemecahan isu & $\begin{array}{c}\text { Siap } \\
\text { diimplementasi }\end{array}$ & Agak detail & Terbuka luas \\
\hline $\begin{array}{l}\text { Tingkat keputusan untuk menangani } \\
\text { isu }\end{array}$ & Kepala Sekolah & Yayasan & Dinas \\
\hline Konsekuensi salah menangani isu & Gangguan & Agak kacau & Kacau sekali \\
\hline Dampak terhadap pihak lainnya & Tidak ada & $\begin{array}{l}\text { Ada }(1 \mathrm{~s} / \mathrm{d} 3 \\
\text { Pihak) }\end{array}$ & $\begin{array}{c}\text { Lebih dari } 4 \\
\text { Pihak }\end{array}$ \\
\hline $\begin{array}{l}\text { Pengaruh terhadap aspek sosial, politik, } \\
\text { ekonomi }\end{array}$ & Lunak & Sedang & Keras \\
\hline
\end{tabular}

Sumber : Tangkilisan, 2003

\section{HASIL DAN PEMBAHASAN}

\section{Identifikasi Nilai-nilai Strategis}

Di dalam penelitian strategi peningkatan kompetensi profesionalisme guru, tahap yang harus dilakukan adalah identifikasi nilai-nilai strategis yaitu kondisi yang mempengaruhi strategi peningkatan kompetensi guru dalam proses belajar mengajar di SMP Kristen Satya Wacana Salatiga, sehingga dapat mengetahui nilai-nilai strategi dalam peningkatan kompetensi guru di SMP Kristen Satya Wacana Salatiga. Salatiga adalah kota yang terletak di Jawa Tengah. Kota yang memiliki pemandangan yang asri dan hawa yang sejuk untuk proses belajar. Tercatat ada sekitar 335 sekolah yang ada di Salatiga sehingga bisa dikatakan cukup untuk kota sekecil ini. Tak heran jika orang luar Salatiga bahkan luar pulau hendak datang untuk menempuh ilmu di kota ini. "Memang tidak bisa dipungkiri bahwa, cenderung negeri yang jadi favorite. Tapi masih banyak orangtua yang menitipkan anaknya di sekolah ini. Karena guru-guru disini memperlakukan anak didik seperti anakanaknya sendiri". (Menurut Suwasono, wawancara pada tanggal 13 Maret 2019).

Dari penjelasan di atas bahwa, banyaknya sekolah di kota ini sehingga banyak lembagalembaga pendidikan mendirikan sekolah salah satunya adalah Universitas Kristen Satya Wacana, lembaga pendidikan ini mempunyai laboratorium dari pendidikan yang mendasar hingga sekolah menengah. Lingkungan yang nyaman membuat Kota Salatiga sangat cocok untuk belajar. Percampuran etnis yang membuat kota ini disebut kota yang mempunyai toleransi yang kuat 
sehingga perbedaan tidak menjadikan masalah di kota ini. Serta dengan tenaga kerja dan sarana prasarana yang mewadai membuat sekolah yang ada di Kota Salatiga tidak diragukan oleh masyarakat dalam dan luar Kota Salatiga.

Tahapan berikutnya yang perlu dibahas dalam menganalisis peningkatan kompetensi profesionalisme guru dalam proses belajar mengajar di SMP Kristen Satya Wacana adalah dengan melakukan analisis lingkungan strategis. Lingkungan strategis terdiri dari lingkungan internal dan juga lingkungan eksternal yang mempengaruhi perumusan strategi peningkatan kompetensi guru. Langkah ini dilakukan setelah melihat kondisi peningkatan kompetensi guru. Menilai lingkungan internal dan eksternal organisasi dimaksudkan untuk mengidentifikasikan kekuatan, kelemahan, peluang dan ancaman yang mungkin akan dihadapi dalam pengelolaan tersebut.

Analisis yang diperlukan dalam lingkungan internal adalah dengan mengidentifikasi dari berbagai faktor yang berasal dari dalam organisasi yang mencakup kekuatan dan kelemahan organisasi. Hal ini dapat dilihat melalui visi dan misi organisasi, pengelolaan yang dilakukan, sumber daya manusia, anggaran yang terkait, infrastruktur yang ada dan budaya organisasi. Berikut uraian dari lingkungan internal :

\section{Visi dan Misi}

Setiap organisasi publik memiliki mandat yang harus diemban dalam rangka penyelenggaraan negara. Hal ini tertuang dalam visi dan misi sebuah organisasi publik. Ketika ditanyakan mengenai mandat Dinas Pendidikan Kota Salatiga kepala sekolah mengungkapkan bahwa : "Memang jika dikaitkan dengan mandat dari dinas memang ada, namun dalam pelaksanaanya belum optimal. Pelatihan yang diberikan tidak berbasis teknologi, hanya seminar dan workshop pada umumnya saja". (Menurut Suwasono, wawancara tanggal 13 Maret 2019).

\section{Anggaran}

Di dalam setiap penyelenggaraan kegiatan, tidak akan terlepas dari anggaran yang tersedia, karena dengan tercukupinya anggaran kegiatan maka kegiatan itu sendiri akan berjalan dengan baik. Akan tetapi jika anggaran yang ada tidak mampu mencukupi kebutuhan dari kegiatan yang diselenggarakan maka akan menjadi penghambat bagi kegiatan tersebut baik secara kualitas maupun kuantitas. Anggaran yang digunakan dalam kegiatan peningkatan kompetensi profesionalisme guru diperoleh dan dikelola dengan menggunakan sistem anggaran instansi yayasan pada umumnya, dengan menyusun rencana kegiatan yang akan dilaksanakan dan yang harus dianggarkan. "Tapi sampai saat ini belum ada anggaran kesitu mbak, masih dalam rencana untuk menumbuhkan peningkatan kompetensi prifesionalisme guru supaya guru gak katrok". (Tutur Suwasono dalam wawancara tanggal 13 Maret 2019).

Hal ini juga dibenarkan oleh Wisnu selaku staf tata usaha : "Ndak, pernah ada mbak anggaran dari yayasasn atau dari pihak luar mengenai peningkatan kompetensi profesionalisme guru. Makanya sampe sekarang ya gitu-gitu aja".

\section{Sumber Daya Manusia}

Untuk menganalisis sumber daya manusia bisa dilihat dari tenaga pendidik di SMP Kristen Satya Wacana hanya ada 11 Guru (Menurut Suwasono). Hal tersebut dibenarkan oleh Suwasono dalam wawancara : "Satu guru saja bisa merangkap satu sampai tiga pekerjaan karena keterbatasan guru yang ada".

Namun berbeda lagi yang dikemukakan oleh Wisnu selaku staff tata usaha : "Bahkan, guru yang seharusnya mengajar TIK sekarang malah mengajar mata pelajaran kesenian, itu kan sudah jauh konteksnya mbak". 


\section{Infrastruktur (Sarana dan Prasarana)}

Sarana dan prasarana dalam lingkungan SMP Kristen Satya Wacana sangat minim untuk melakukan kegiatan. Karena sarana dan prasarana akan dijadikan sebagai pendukung kegiatan dalam melakukan aktivitas. "Jaringan internet dengan letak laboratorium juga menjadi kendala untuk melakukan aktifitas di sekolah. Namun, kegiatan yang berkaitan dengan kepemimpinan, retreat, kemah masih dilakukan untuk menunjang karakter anak". (Menurut Suwasono dalam wawancara tanggal13 Maret 2019).

Namun, dalam segi pembelajaran sekolah ini sudah merancang dari awal bentuk sekolahnya minimalis ruangan agar siswa dapat konsentrasi belajar. Pendapat tersebut dibenarkan oleh Suwasono, selaku kepala sekolah : "Bahwa, sekolah didesain dengan ruangan kecil-kecil biar guru dan siswa juga konsentrasi dalam belajar mengajar. Wong guru juga sudah bisa pakai LCD, laptop tapi ya terbatas penggunaannya".

Bukan hanya keterbatasan sumber daya manusianya namun, fasilitas yang kurang mewadai juga dirasakan oleh siswa di sekolah ini. Pernyataan tersebut diungkapan juga dalam wawancara : "Aku juga pengen kak, sekolah pakai komputer atau laptop yang pelajarannya gak dengerin guru ceramah. Aku bosen (sambil ketawa). Ngebosenin, ga ada pembaharuan kalo ngajarnya gitu-gitu aja. Terus pengen juga, bawa hp ke skolah kan biar bisa mengupdate pengetahuan lewat internet. Guru-guru disini juga ga semua pakai komputer jadi ngajarnya ya gitu-gitu aja ga ada yang baru gitu loh kak". (Menurut Yotam siswa kelas VII, pada wawancara 01 April 2019).

Pendapat lain juga dikemukan oleh Jovan siswa kelas VII , pada wawancara yang sama beliau mengemukakan : "Aku juga pengennya guru-guru juga bisa pakai laptop buat power point, malahan yang pakai PPT seringnya mahasiswa PPL. Enaknya, bisa jelas gitu kalo pake kayak gitu (Sambil ketawa kecil)".

\section{Budaya Organisasi}

Sistem yang dianut untuk melakukan kegiatan bersama-sama di lingkungan tersebut guna memaknai nilai yang terkadung di dalamnya secara bersama-sama. Pendapat Suwasono selaku kepala sekolah waktu itu bahwa: "Guru bisa melakukan tugas dan tanggung jawabnya secara bersamaan. Bisa jadi kepala sekolah, namun harus mengajar beberapa kelas, ada juga menjadi wali kelas tapi merangkap mengajar mapel lainnya"

Hal tersebut juga dibenarkan oleh Wisnu selaku staff tata usaha :

"Lah wong guru pelajaran TIK saja bisa guru kesenian, saya yang jadi staff saja bisa melakukan pekerjaan lain mbak. Kadang, anter minum, bersih-bersih, ya pokoknya yang perangkat keras juga saya kerjakan".

Berbeda lagi dengan pendapat guru lainnya, Natalia Prabandari wawancara pada tanggal 01 April 2019 mengungkapkan bahwa : "Budaya organisasi yang ada di sekolah ini kurang efektif, memang guru mengajar pada bidangnya. Tapi, tidak dengan saya dengan permen yang baru kemudian kurikulum 2006 ke kurikulum 2013. Ya, saya ngikut kebijakan yang ada. Gatau, sekolah ini bagaimana intinya ya saya tetap memperjuangkan apa yang menjadi prinsip saya". (Secara tidak langsung beliau ingin sekolah ini maju dalam teknologi).

\section{Analisis Lingkungan Eksternal}

Dalam menganalisi lingkungan eksternal adalah dengan mengidentifikasi tentang berbagai komponenen yang berpengaruh pada peluang dan ancaman yang berasal dari luar organisasi. Faktor-faktor tersebut adalah dukungan dari dinas, dukungan dari gereja, dukungan dari masyarakat, dukungan stakeholder, dukungan yayasan, faktor teknologi, faktor ekonomi, faktor geografis, faktor sosial dan budaya, sekolah pesaing. Berikut analisis lingkungan ekternal : 


\section{Dukungan Dinas}

Dukungan dinas sangat diperlukan untuk menganalisis strategi peningkatan kompetensi profesionalisme guru. Dukungan dinas ini diungkapkan dalam wawancara Kepala sekolah : "Kalo dari dinas itu gak ada mbak, cuman komputer aja itu dari pemerintah 32 komputer. Kalo yang mengenai kompetensi profesionalisme guru belum pernah. Beda lagi dengan sekolah negeri kalau hal yang berbau teknologi. Kalo bantuan lain-lainnya gak ada. Pelatihan juga belum kalo yang berbau teknologi. Hanya sebatas seminar, itupun guru yang mapel UN (Ujian Nasional)".

Perihal ini juga disampaikan oleh Wisnu selaku tata usaha: "Memang belum pernah ada mbak guruguru disini yang mengikuti pelatihan yang mengenai teknologi dari dinas, cuman seminar biasa aja paling kalo ada undangan dari dinas ya sekolah di undang. Ya sebatas itu saja."

\section{Dukungan Gereja}

Dukungan gereja juga sangat dibutuhkan dalam sekolah yang bernuansa nasrani. Dalam bentuk dukungan apapun gereja juga sangat membantu untuk meningkatkan kompetensi yang dimiliki guru. Pendapat ini disampaikan oleh Suwasono selaku kepala sekolah : "Kalo, dukungan dari gereja ya cuman minta tolong pendeta kasih khotbah acara retreat. Gak, berkaitan untuk meningkatkan kompetensi guru-guru disini. Apalagi, kalo sangkut pautnya di uang. Kadang-kadang kita ya memanfaatkan gereja untuk menumbuhkan karakter anak.

Pendapat ini juga dibenarkan oleh Wisnu : "(Ketawa) sekolah tidak pernah diberi bantuan berupa uang mbak, ya hanya sekedar penunjang kegiatan retreat nanti pendeta bantu bawakan khotbah. Ya, hanyahanya itu saja".

\section{Dukungan Masyarakat}

Dukungan masyarakat dalam menganalisis strategi peningkatan profesionalisme guru juga penting. Dengan keberadaan masyarakat bisa dikatakan orang tua murid. Pendapat ini diungkapkan oleh Suwasono tentang dukungan masyarakat dalam wawancara : "Kalo, dari orang tua murid sendiri pokoknya urusan pendidikan diserahkan oleh pihak sekolah. Tidak mau tau akan hal itu karena menurut mereka sekolah ini bisa mendidik anak-anaknya. Tapi, untuk masyarakat sekitar sekolah membantu dalam hal parkir kendaraan jika di sekolah ada kegiatan. Mereka juga lihatnya dari pelayanan guru di sekolah ini yang menganggap anak murid seperti anak sendiri."

Hal ini juga dibenarkan oleh Wisnu bahwa : "Gak ada ya mbak hehehe (ketawa)."

\section{Dukungan Stakeholder}

Dukungan dari stake holder sangat perlu, yang dimaksud dengan stake holder sendiri adalah suatu masyarakat/ kelompok yang memliki hubungan dan kepentingan terhadap organisasi atau perusahaan. Namun, stake holder adalah yang berkaitan dengan finansial/keuangan. Oleh, karena itu dukungan dari stakeholder juga sangat membantu dalam meningkatkan program sekolah. "Ya, seperti yang saya bilang komite tadi. Mereka hanya sebatas membantu dalam kegiatan sekolah seperti retreat dan kegiatan paskah atau kegiatan lainnya." (Menurut Suwasono, wawancara pada tanggal 13 Maret 2019)

\section{Dukungan Yayasan}

Yayasan Perguruan Tinggi Kristen Satya Wacana merupakan wadah yayasan bagi sekolahsekolah yang ada di Kota Salatiga. Salah satunya, adalah SMP Kristen Satya Wacana Salatiga. Jadi, dukungan dari yayasan itu juga sangat membantu dalam program-program yang akan dilaksanakan oleh pihak sekolah. Hal ini diungkapkan oleh Suwasono : "Karena, sekolah ini di bawah yayasan jadinya kita punya program apa baru datang ke mereka. Tapi, sejauh ini belum ada proposal yang kami ajukan untuk yang berkaitan dengan profesionalisme guru." 


\section{Faktor Teknologi}

Perkembangan teknologi yang pesat sekarang ini memberikan pengaruh dalam setiap kehidupan manusia, baik positif maupun negatif. "Ya, yang jadi hambatan adalah guru-guru hanya tau power point saja. Itupun yang normal-normal sebatas begitu saja. Karena, tidak semua ruangan memakai jaringan internet. Hambatannya disini karena peraturan tidak boleh bawa HP (Hand-Phone). Tapi kalau ada tugas anak presentasi juga pake laptop sekolah juga menyediakan LCD. Tapi, tetap kalau tugas yang lain masih pakai kertas. Belum bisa pake yang kaya link atau semacam google classroom. (Menurut Suwasono, wawancara 13 Maret 2019)

\section{Faktor Ekonomi}

Faktor ekonomi bukan jadi penghambat para orang tua untuk menyekolahkan anak-anak mereka di SMP Kristen Satya Wacana Salatiga. Karena, sekolah ini mempunyai program untuk membantu siswa yang ingin sekolah disini tapi kondisi ekonomi orang tua tidak mencukupi. Oleh sebab itu, pihak sekolah mempunyai program dalam mengolah keluar masuknya uang. "Yang membuat beda dari sekolah lain adalah karakteristiknya, dan program-program disini. Itu yang banyak membuat mereka mempercayakan anak-anaknya kepada sekolah ini." (Menurut Suwasono, wawancara tanggal 13 Maret 2019)

$\mathrm{Hal}$ ini juga dibenarkan oleh Wisnu, beliau mengungkapkan bahwa : "Tidak hanya orang tua yang ada bisa sekolah disini, tapi ada orang tua siswa yang kurang mampu tapi ingin menyekolahkan anaknya disini. Toh, sekolah juga gak diem aja. Tetep bantu dalam hal keuangan. Jadi ekonomi tidak menjadi penghambat buat mereka yang ingin sekolah disini. Karena ada bantuan juga yang berupa iuran sebesar Rp. 20.000 -, untuk membantu anak-anak yang kurang mampu.

\section{Faktor Geografis}

Letak geografis suatu wilayah memberikan pengaruh pada penyelenggaraan kegiatan pemerintahan, baik sebagai faktor mendukung maupun faktor penghambat. "Dilihat dari bangunan yang orang pikirkan adalah ketika masuk, dan naik. Kenapa bisa begitu, karena ketika masuk sudah jauh dari depan untuk berjalan. Ketika naik harus ada beberapa anak tangga yang harus dinaiki oleh kaki. Jadi, orang yang niat sekolah disini sudah tau konsekuensinya. Jadi yang diawal maksud sudah tau." (Menurut Suwasono)

\section{Faktor Sosial dan Budaya}

Faktor sosial dan budaya juga mempengaruhi peningkatan profesionalisme guru di sekolah ini. Karena upaya yang dilakukan oleh guru disini mengupayakan yang terbaik untuk anak didiknya. "Sosial dan budayanya sekolah ini bisa dikatakn standart ya, kami mengikuti aturannya. Ada kegiatan yang berbau baksos. Sosialnya juga bisa dikatakan sangat sosial. Banyak anak yang sekolah disini tapi orang tuanya kurang mampu, sekolah tetap mengupayakan supaya anak itu bisa sekolah disini. Jadi budaya dan sosial disini bisa dikatakan sudah bagus." (Menurut Wisnu selaku tata usaha).

\section{Sekolah Pesaing}

Sekolah merupakan pendidikan yang harus ditempuh oleh setiap orang untuk memperluas pendidikannya. Banyak, sekolah yang bagus dan populer. Namun, tergantung dari sudut pandang seseorang bagaimana menilai sesuatu dari pengamatan. "Sejauh ini sepengamatan saya banyak orang tua yang menyekolahkan anaknya di negeri. Karena kan buku dan uang sekolah gratis." (Menurut Wisnu selaku tata usaha). 


\section{Analisis SWOT Lingkungan Strategis}

Analisis ini dilandasi oleh keyakinan terhadap asumsi bahwa strategi efektif akan mampu memaksimalkan kekuatan dan mengeksploitasi peluang serta disaat bersamaan mampu meminimalisir kelemahan dan berbagai ancaman. Dasar analisis ini adalah setelah kita melakukan analisis lingkungan internal dan lingkungan eksternal organisasi. Setelah itu barulah kita dapat memetakan hal mana saja dari lingkungan internal yang menjadi kelemahan dan kekuatan. Kemudian hal mana saja dari lingkungan eksternal yang menjadi ancaman dan peluang. Berdasarkan hasil penelitian yang telah dilakukan, maka dapat disimpulkan dengan peluang dan ancaman yang dihadapi, dipaparkan sebagai berikut :

Tabel 3. Matrik Analisis SWOT

\begin{tabular}{|c|c|c|}
\hline Faktor Eksternal & $\begin{array}{l}\text { STRENGTHS (S) } \\
\text { 1. Harapan siswa yang suka } \\
\text { teknologi } \\
\text { 2. Laboratorium Komputer } \\
\text { 3. Fasilitas jaringan di } \\
\text { lingkungan kantor guru }\end{array}$ & $\begin{array}{l}\text { WEAKNESSES (W) } \\
\text { 1. Sarana prasarana sekolah } \\
\text { dan yayasan yang kurang } \\
\text { memadai } \\
\text { 2. Kuantitas SDM di SMP } \\
\text { Kristen Satya Wacana } \\
\text { Salatiga yang terbatas } \\
\text { 3. Minimnya anggaran } \\
\text { yayasan dan sekolah } \\
\text { 4. Belum ada pelatihan yang } \\
\text { berbasis teknologi untuk } \\
\text { guru-guru } \\
\text { 5. Masih kurangnya } \\
\text { pemanfaatan fasilitas } \\
\text { jaringan internet } \\
\text { 6. Masih ada beberapa guru } \\
\text { yang belum mengetahui } \\
\text { tentang bagaimana } \\
\text { meningkatkan kompetensi } \\
\text { profesionalisme guru }\end{array}$ \\
\hline $\begin{array}{l}\text { OPPORTUNITIES (O) } \\
\text { 1. Kondisi laboratorium yang } \\
\text { luas untuk mengasah anak } \\
\text { belajar bersama guru melalui } \\
\text { jaringan internet } \\
\text { 2. Keberadaan teknologi } \\
\text { mendukung guru untuk } \\
\text { meningkatkan kompetensi } \\
\text { guru } \\
\text { 3. Adanya stakeholders yang } \\
\text { terjalin } \\
\text { 4. Adanya yayasan yang sudah } \\
\text { mengatur untuk keperluan } \\
\text { keuangan } \\
\text { 5. Letak strategis kondisi di } \\
\text { tengah kota }\end{array}$ & $\begin{array}{l}\text { STRATEGI S - O } \\
\text { 1. Peningkatan program kegiatan } \\
\text { pelatihan kompetensi guru } \\
\text { 2. Peningkatan kerja sama } \\
\text { dengan stakeholders serta } \\
\text { yayasan profesionalisme guru } \\
\text { 3. Peningkatan penggunaan } \\
\text { fasilitas yang ada di sekolah }\end{array}$ & $\begin{array}{l}\text { STRATEGI W - O } \\
\text { 1. Kerjasama dengan } \\
\text { stakeholders dan yayasan } \\
\text { guna mengatasi minimnya } \\
\text { anggaran operasional } \\
\text { kegiatan } \\
\text { 2. Peningkatan sarana } \\
\text { prasarana utama } \\
\text { pendukung upaya } \\
\text { peningkatan kompetensi } \\
\text { guru } \\
\text { 3. Peningkatan SDM dalam } \\
\text { meningkatkan kompetensi } \\
\text { guru }\end{array}$ \\
\hline
\end{tabular}




\begin{tabular}{|c|c|c|}
\hline $\begin{array}{l}\text { THREATS (T) } \\
\text { 1. Kurangnya kerja sama } \\
\text { alumni komite pemegang } \\
\text { 2. Masih rendahnya keahlian } \\
\text { dan keterampilan tenaga } \\
\text { kerja } \\
\text { 3. Masih rendahnya motivasi } \\
\text { dan komitmen kerja dari } \\
\text { tenaga kerja } \\
\text { 4. Kurang aktifnya pihak swasta } \\
\text { (yayasan) untuk mengetahui } \\
\text { program yang akan } \\
\text { ditingkatkan oleh pihak } \\
\text { sekolah } \\
\text { 5. Pola pikir guru yang masih } \\
\text { enggan untuk belajar tentang } \\
\text { teknologi. } \\
\text { 6. Orang tua yang acuh } \\
\text { terhadap kompetensi guru } \\
\text { 7. Tidak ada dukungan dari } \\
\text { gereja }\end{array}$ & $\begin{array}{l}\text { STRATEGI S - T } \\
\text { 1. Meningkatkan hubungan } \\
\text { relasi antar stakeholders dan } \\
\text { yayasan mengenai } \\
\text { peningkatan kompetensi guru } \\
\text { 2. Meningkatkan hubungan guru } \\
\text { dengan orang tua guna } \\
\text { mengetahui kinerja guru } \\
\text { 3. Meningkatkan motivasi dan } \\
\text { komitmen kerja dari tenaga } \\
\text { kerja } \\
\text { 4. Membangun relasi alumni } \\
\text { komitemen pemegang saham }\end{array}$ & $\begin{array}{l}\text { STRATEGI W-T } \\
\text { 1. Peningkatan kompetensi } \\
\text { guru yang berbasis } \\
\text { teknologi } \\
\text { 2. Peningkatan fasilitas } \\
\text { jaringan internet yang ada } \\
\text { di ruangan guru } \\
\text { 3. Peningkatan kebijakan } \\
\text { dari sekolah mengenai } \\
\text { kompetensi guru } \\
\text { 4. } \text { Menjalin relasi dengan } \\
\text { pihak gereja dan } \\
\text { stakeholders }\end{array}$ \\
\hline
\end{tabular}

\section{Identifikasi Isu-isu Strategis}

Berdasarkan matriks SWOT yang telah dijelaskan sebelumnya, maka langkah selanjutnya adalah mengidentifikasi isu-isu strategis. Sesuai dengan hasil analisis SWOT yang telah dilakukan pada hasil penelitian lingkungan internal dan lingkungan eksternal peningkatan kompetensi guru, maka dapat dimunculkan beberapa alternatif strategi yang mungkin difokuskan pada pembentukan perencanaan strategis bagi peningkatan kompetensi guru dalam proses belajar mengajar di SMP Kristen Satya Wacana Salatiga melalui identifikasi isu-isu strategis. Adapun strategi hasil analisis SWOT tersebut meliputi :

\section{Strategi S - O}

Strategi yang bersumber dari Strengths dan Opportunities ini merupakan sebuah strategi dalam perumusan peningkatan kompetensi yang dimiliki guru dengan peluang dan kekuatan yang ada. Kekuatan yang berasal dari lingkungan internal kemudian dirumuskan untuk mengambil peluang dari lingkungan eksternal yang ada dalam peningkatan kompetensi guru dalam proses belajar mengajar di SMP Kristen Satya Wacana Salatiga. Strategi yang di ambil adalah sebagai berikut : Peningkatan program kegiatan pelatihan kompetensi guru. Pelatihan kompetensi sangat penting untuk guru di zaman sekarang, maka perlunya pelatihan agar dapat menyampaikan materi di kelas dengan baik. Banyak metode yang dipakai guru untuk memberikan materi. Karena dengan harapan siswa yang ada di sekolah ini ingin para guru menggunakan aplikasi untuk mengajar supaya ada pembaharuan dari guru kepada siswa dalam mengajar.

Peningkatan kerja sama dengan stakeholders serta yayasan. Kerja sama yang dilakukan pihak sekolah dengan stakeholders serta yayasan sangat perlu dilakukan. Menjalin relasi untuk mengevalusi tentang kinerja yang ada di internal sangat membantu dalam mengatasi permasalahan yang ada. Karena pemegang keuangan dalam sekolah ini bersumber dari yayasan dan stakeholders. Jika, sekolah dengan dua pihak tersebut bisa menyampaikan keadaan yang terjadi maka permasalahan dalam meningkatkan kompetensi guru dapat terkendali. 
Peningkatan penggunaan fasilitas yang ada di sekolah. Fasilitas sangat diperlu guna menunjang proses pembelajaran. Jika sekolah mempunyai fasilitas yang mewadai untuk proses belajar mengajar maka kegiatan pembelajaran akan berlangsung sangat baik. Fasilitas yang ada contohnya, jaringan internet di lingkungan sekolah, pemakaian handphone saat diperlukan untuk mengakses pembelajaran, memanfaatkan laboratorium komputer untuk kegiatan proses belajar mengajar.

\section{Strategi W - O}

Kerjasama dengan stakeholders dan yayasan guna mengatasi minimnya anggaran operasional kegiatan. Kerjasama yang dilakukan oleh sekolah seharusnya lebih rutin karena untuk mengetahui program-program yang ada. Jika pihak stakeholders atau bisa dikatakan komite itu mengetahui apa yang diperlukan oleh guru maka akan terjalinnya komunikasi yang bagus guna menunjang peingkatan kompetensi guru dalam mengajar.

Peningkatan sarana prasarana utama pendukung upaya peningkatan profesionalisme. Pendukung sarana dan prasarana itu juga sangat penting untuk di lingkungan sekolah. Jaringan yang luas serta pemakaian barang elektronik di zaman sekarang juga sangat menunjang dalam hal pendidikan. Karena semua pengetahuan bisa diakses melalui jaringan internet dan aplikasi yang berhubungan dengan teknologi. Peningkatan SDM dalam meningkatkan kompetensi guru. Dalam menjalankan tugas dan tanggungjawabnya sebagai pendidik, seorang guru juga dituntut untuk sadar dalam komitmen melakukan tugasnya. Faktor yang menjadi penghambat terkadang bukan hanya dari siswa, namun pihak guru juga akan berpengaruh bagi aktivitas yang dilakukan. Siswa aktif justru kadang guru yang malas-malasan dalam menyampaikan materi.

\section{Strategi S-T}

Meningkatkan hubungan relasi antar stakeholders dan yayasan mengenai peningkatan kompetensi guru. Hubungan yang baik akan berpengaruh pada kinerja seseorang. Ada programprogram kerja yang dibagikan ketika ada pertemuan besar, agar semua mengetahui apa yang harus dirancang, apa yang harus dimulai, apa yang harus dikerjakan dan apa yang harus dibenahi ketika ada sebuah rencana yang berkaitan dengan peningkatan kompetensi guru. Meningkatkan hubungan guru dengan orang tua guna mengetahui kinerja guru. Dengan meningkatkan hubungan guru dengan orang tua maka terjalinlah hubungan yang baik antar kedua belah pihak untuk menyampaikan informasi. Saling bertukar informasi yang harus dilakukan oleh pihak sekolah mengenai kompetensi guru, juga bisa menyampaikan informasi tentang perkembangan peserta didik. Meningkatkan motivasi dan komitmen kerja dari tenaga kerja. Motivasi dalam bekerja itu penting. Jika seseorang tidak memiliki motivasi yang benar maka akan berpengaruh bagi kinerjanya. Bisa dilakukan dengan perkumpulan antar guru, pihak yayasan bahkan komite untuk berbagi bersama guna membangun sekolah dengan lebih baik. Membangun relasi alumni. Membangun relasi bukan hanya dengan yayasan atau pihak gereja, namun dengan alumni yang pernah sekolah di SMP Kristen Satya Wacana Salatiga itu juga sangat membantu. Dengan adanya kegiatan pertemuan alumni juga bisa meningkatkan sekolah untuk lebih baik.

\section{Strategi W-T}

Peningkatan kompetensi guru yang berbasis teknologi Teknologi di era zaman sekarang sangatlah penting guna menunjang pendidikan. Wawasan pengetahuan akan bertambah banyak ketika kita dapat belajar dari teknologi berupa aplikasi yang berhubungan dengan internet. Guru seharusnya bisa memanfaatkan fasilitas yang ada di sekolah untuk belajar aplikasi guna menyampaikan materi ajar yang dibagikan di kelas. Peningkatan fasilitas jaringan internet. 
Dalam melengkapi sarana dan prasarana sekolah jaringan internet juga diperlukan. Dengan, memperluas jaringan internet yang ada di sekolah baik guru maupun siswa juga dapat mengakses pengetahuan lewat teknologi yang digunakannya. Bisa, melalui gadget atau laptop. Peningkatan kebijakan dari sekolah mengenai kompetensi guru. Jika sekolah mempunyai kebijakan tentang peraturan bahwa guru harus bisa mengoperasikan komputer maka sekolah ini juga akan berkembang dengan bagus. Karena pihak siswapun ingin jika guru-guru yang ada di SMP Kristen Satya Wacana dapat menggunakan aplikasi teknologi di zaman sekarang supaya ada inovasi dalam mengajar di kelas. Menjalin relasi dengan pihak gereja dan stakeholders. Menjalin relasi dengan pihak gereja juga berpengaruh dengan bantuan dari gereja berupa motivasi kepada pihak sekolah (guru, staf dan siswa) melalui kegiatan yang berkaitan dengan rohani bisa juga dilakukan dengan kegiatan retreat dengan komite, alumni, dan donatur.

\section{Evaluasi Isu Strategis}

Setelah dirumuskan isu strategis maka tahap selanjutnya adalah evaluasi isu strategis. Pada tahap ini akan diukur tingkat kestrategisan isu agar dapat diketahui seberapa besar kontribusi isu tersebut terhadap eksistensi dan keberhasilan organisasi dalam upaya pencapaian tujuan, sebagai alat ukurnya dipergunakan alat uji litmus (Litmus Test). Untuk membantu dalam perumusan strategis suatu isu, maka kriteria sesuai dengan pengukuran maka: 1) Jawaban yang sifatnya strategis diberikan nilai bobot 3; 2) Jawaban yang sifatnya moderat diberikan nilai bobot 2; dan 3) Jawaban yang sifatnya operasional diberikan nilai bobot 1 .

Berdasarkan pada keempat kelompok isu strategis di atas, maka dapat dirumuskan isu-isu strategis utama strategi peningkatan kompetensi guru dalam proses belajar mengajar di SMP Kristen Satya Wacana Salatiga adalah sebagai berikut :

Tabel 3. Hasil Tes Litmus Strategi Peningkatan Kompetensi Guru Dalam Proses Belajar Mengajar

\begin{tabular}{|c|c|c|c|c|c|c|c|c|c|c|c|c|c|c|}
\hline \multirow{3}{*}{ Pertanyaan Pokok } & \multicolumn{14}{|c|}{ Strategi } \\
\hline & \multicolumn{3}{|c|}{ S-O } & \multicolumn{3}{|c|}{ W-O } & \multicolumn{4}{|c|}{ S-T } & \multicolumn{4}{|c|}{ W-T } \\
\hline & 1 & 2 & 3 & 4 & 5 & 6 & 7 & 8 & 9 & 10 & 11 & 12 & 13 & 14 \\
\hline $\begin{array}{l}\text { Kapan } \\
\text { peluang/tantangan isu } \\
\text { yang anda hadapi }\end{array}$ & 3 & 3 & 2 & 3 & 2 & 1 & 3 & 2 & 3 & 2 & 3 & 2 & 2 & 1 \\
\hline Seberapa luas isu ini & 3 & 2 & 2 & 2 & 3 & 2 & 3 & 2 & 3 & 3 & 2 & 2 & 2 & 2 \\
\hline $\begin{array}{l}\text { Seberapa besar biaya } \\
\text { yang diperlukan }\end{array}$ & 3 & 3 & 3 & 2 & 2 & 2 & 2 & 2 & 2 & 3 & 3 & 3 & 3 & 2 \\
\hline $\begin{array}{l}\text { Pendekatan terbaik bagi } \\
\text { pemecahan isu }\end{array}$ & 3 & 3 & 2 & 3 & 3 & 2 & 3 & 2 & 2 & 2 & 3 & 2 & 2 & 1 \\
\hline $\begin{array}{l}\text { Tingkat keputusan } \\
\text { untuk menangani isu }\end{array}$ & 3 & 3 & 3 & 3 & 3 & 3 & 2 & 2 & 2 & 2 & 2 & 3 & 2 & 2 \\
\hline $\begin{array}{l}\text { Konsekuensi salah } \\
\text { menangani isu }\end{array}$ & 1 & 2 & 3 & 1 & 1 & 1 & 3 & 1 & 1 & 1 & 1 & 1 & 1 & 1 \\
\hline $\begin{array}{l}\text { Dampak terhadap } \\
\text { pihak lainnya }\end{array}$ & 1 & 1 & 2 & 1 & 1 & 1 & 1 & 1 & 1 & 1 & 1 & 1 & 1 & 1 \\
\hline $\begin{array}{l}\text { Sensitivitas isu terhadap } \\
\text { aspek politik, ekonomi, } \\
\text { sosial dan budaya }\end{array}$ & 2 & 2 & 2 & 1 & 1 & 2 & 2 & 1 & 2 & 2 & 2 & 2 & 2 & 2 \\
\hline Jumlah & 19 & 19 & 19 & 16 & 16 & 14 & 19 & 13 & 16 & 16 & 17 & 16 & 15 & 12 \\
\hline
\end{tabular}


Setelah dilakukan pemberian skor, dilakukan perhitungan skor masing-masing isu strategis. Isu yang benar-benar strategis adalah isu yang memiliki skor tinggi pada semua dimensi. Suatu isu yang benar-benar operasional adalah isu dengan skor rendah dalam semua dimensi (Bryson, 2007). Tabel di atas merupakan hasil perhitungan skor masing-masing isu strategis yang diuji dengan Uji Litmus (Litmus Test). Hasil perhitungan tersebut dapat diklasifikasi berdasarkan urutan prioritas sebagai berikut :

Tabel 4. Klasifikasi isu-isu strategis

\begin{tabular}{lc}
\hline \multicolumn{1}{c}{ Isu Strategis } & Skor \\
\hline Peningkatan program kegiatan pelatihan kompetensi guru & 19 \\
Peningkatan kerja sama dengan stakeholders serta yayasan & 19 \\
Peningkatan penggunaan fasilitas yang ada di sekolah & 19 \\
$\begin{array}{l}\text { Kerjasama dengan stakeholders dan yayasan guna mengatasi } \\
\text { minimnya anggaran operasional kegiatan }\end{array}$ & 16 \\
Peningkatan sarana prasarana utama pendukung upaya peningkatan & 16 \\
kompetensi & 14 \\
Peningkatan SDM dalam meningkatkan kompetensi guru & 19 \\
Meningkatkan hubungan relasi antar stake holders dan yayasan & 13 \\
mengenai peningkatan kompetensi guru & 16 \\
Meningkatkan hubungan guru dengan orang tua guna mengetahui & 16 \\
kinerja guru & 17 \\
Meningkatkan motivasi dan komitmen kerja dari tenaga kerja & 16 \\
Peningkatan kompetensi guru yang berbasis teknologi & 15 \\
Peningkatan fasilitas jaringan internet yang ada di ruangan guru & 12 \\
Peningkatan kebijakan dari sekolah mengenai kompetensi guru & 13 \\
Menjalin relasi dengan pihak gereja dan stakeholders & \\
\hline
\end{tabular}

Menurut (Moleong, 2007) ada sedikitnya tiga macam isu strategis, masing-masing butuh diperlakukan secara berbeda, yaitu (1) isu yang tidak membutuhkan tindakan sekarang, tetapi harus dipantau, (2) isu yang bisa ditangani sebagai bagian dari siklus perencanaan strategis regular organisasi, dan (3) isu yang membutuhkan perhatian segera dan harus ditanggulangi di luar siklus perencanaan strategis regular organisasi (Bryson, 2007 : 186).

Dari hasil klasifikasi isu strategis tersebut, diketahui urutan prioritas penyelesaian dari masing-masing isu. Isu strategis yang memiliki skor paling tinggi adalah peningkatan program kegiatan pelatihan kompetensi guru. Walaupun dari kesemua isu strategis tersebut memiliki skor yang tidak jauh berbeda antara satu dan yang lainnya. Isu-isu inilah yang kemudian akan dirumuskan ke dalam program-program strategis.

\section{Perumusan Strategi Peningkatan Kompetensi Guru}

Berdasarkan hasil analisis identifikasi isu-isu strategis yang telah dipaparkan, akan dijadikan sebagai sebuah acuan dalam perumusan strategi peningkatan kesempatan kerja. Strategi peningkatan merupakan sebuah rencana yang disusun guna mendukung capaian hasil yang optimal atas rumusan strategi yang selama ini telah dilaksanakan dalam peningkatan kompetensi guru di SMP Kristen Satya Wacana. Sehingga perumusan program yang akan disusun saat ini selain bertolak pada strategi yang sedang dilaksanakan juga bersumber dari hasil temuan isu-isu strategis. Hal tersebut akan lebih mudah dilaksanakan jika telah dibuat menjadi sebuah rumusan program strategis. Upaya perumusan program strategis guna mengoptimalisasikan peningkatan 
kompetensi guru adalah sebagai berikut : Peningkatan program yang menunjang kompetensi guru di SMP Kristen Satya Wacana Salatiga dapat dilakukan dengan 1) Kegiatan pelatihan keterampilan penggunaan teknologi dalam proses belajar mengajar; 2) Kegiatan workshop atau pelatihan tenaga kerja dalam ataupun luar kota yang berbasis teknologi; 3) Kegiatan pelatihan kewirausahaan dan pemberian bantuan alat praktik; dan 4) Peningkatan kelengkapan fasilitas seperti sarana dan prasarana komputer, LCD, jaringan internet, dan penggunanaan teknologi baik guru maupun siswa. Kegiatan-kegiatan di atas dapat ditingkatkan kualitas dan kuantitasnya secara bertahap dari tahun ke tahun. Untuk jangka waktu pelaksanaan kegiatan-kegiatan tersebut dapat disesuaikan dengan kebutuhan.

Peningkatan kerja sama dengan stakeholders dan penguatan kerja sama dengan variasi stakeholders lain dalam teknis kegiatan peningkatan kompetensi guru di SMP Kristen Satya Wacana Salatiga. Adapun kerja sama yang dimaksud disini adalah bantuan secara teknis dari dukungan dinas, dukungan gereja, dukungan masyarakat, dukungan stakeholders dan dukungan dari yayasan dengan cara: 1) Menjalin hubungan atau pendekatan secara personal melalui skala prioritas dimulai dari pembentukan wadah komunikasi antara dinas dengan pihak sekolah dapat menggunakan melalui media website dinas dan 2) Pemberian pengetahuan dan pemahaman tentang fungsi dan peran peningkatan kompetensi guru. Kegiatan yang dapat dilakukan adalah seminar atau dialog dua arah dengan mengikutsertakan para tenaga pendidik terutama yang memiliki komitmen dan kepedulian terhadap peningkatan kompetensi guru.

Peningkatan sarana prasarana utama pendukung peningkatan kompetensi guru. Adapun peningkatan sarana prasarana utama dinas dan yayasan secara bertahap dan dengan skala prioritas, dapat dilakukan pemenuhan kelengkapan sarana prasarana kantor seperti peralatan sekolah, laboratorium komputer, dan jaringan internet yang diperluas.

Sosialisasi tentang pelatihan kompetensi guru yang berbasis teknologi dilakukan dengan: 1) Penyelenggaraan seminar atau dialog dua arah pelatihan kompetensi guru dan usaha mandiri di tingkat sekolah-sekolah. Adapun kegiatan pelatihan berupa seminar atau dialog dua arah dapat dilakukan dengan mengundang pihak dinas pendidikan, dan pihak sekolah atau badan teknologi pendidikan supaya dapat menginspirasi sekolah dan 2) Penggalakan kompetensi guru dengan cara pemberian bantuan modal berupa pelatihan menggunakan teknologi di dunia pendidikan.

\section{SIMPULAN}

Upaya peningkatan kompetensi guru menciptakan suatu strategi guna mencapai visi yang ditetapkan. Setelah menganalisis dengan analisis SWOT dengan mengetahui lingkungan eksternal dan lingkungan internal, kemudian merumuskan strategi dengan menggunakan diagram matrik dan mencari skor dengan uji Litmus untuk membuktikan strategi mana yang harus segera dilakukan. Sesuai dengan langkah-langkah penelitian maka prioritas strategi yang dapat dilakukan sebagai berikut: 1) Peningkatan program kegiatan pelatihan kompetensi guru berbasis teknologi; 2) Peningkatan kerja sama dengan stakeholders serta yayasan; 3) Peningkatan penggunaan fasilitas yang ada di sekolah; 4) Peningkatan sarana dan prasarana utama pendukung upaya peningkatan kompetensi; 5) Peningkatan SDM dalam meningkatkan kompetensi guru; 6) Meningkatkan hubungan guru dengan orang tua guna mengetahui kinerja guru; 7) Meningkatkan motivasi dan komitmen kerja dari tenaga kerja; 8) Membangun relasi alumni; 9) Peningkatan fasilitas jaringan internet; 10) Peningkatan kebijakan dari sekolah mengenai kompetensi guru; dan 11) Menjalin relasi dengan pihak gereja 
Jurnal Ekonomi \& Pendidikan, 18(1), 2021

\section{DAFTAR PUSTAKA}

Bryson, M John. 2007. Perencanaan Strategis Bagi Organisasi Sosial. Yogyakarta: Pustaka Pelajar

David, R Fred. 2009. Strategic Management, Manajemen Strategik Konsep. Jakarta : Salemba Empat.

http://www.ivet.ac.id/universitas-ikipsemarang.php

Masyur, Hadi. 2011. Strategi Manajemen Peningkatan Mutu Pendidikan Yang Berorientasi Pada Kepuasan Siswa: Analisis Pelayanan Pendidikan Pada Siswa Pendidikan Dasar dan Menengah di Kota Bandung. Repository Indonesia University of Education.

Moleong, Lexy J. 2007. Metodologi Penelitian Kualitatif. Bandung: PT. Remaja Rosdakarya.

Mustofa. 2007. Upaya Pengembangan Profesionalisme Guru Di Indonesia. Jurnal Ekonomi dan Pendidikan. Volume 4 Nomor 1.

Nurhayati. Emmy. 2018. Strategi Peningkatan Produktivitas Untuk Mencapai Target Produktivitas dan Efisiensi Perusahaan. IEJST (Industrial Engineering Journal of The University of Sarjanawiyata Tamansiswa). Volume 2 Nomor 1.

PP No. 19 Tahun 2005 tentang Standar Nasional Pendidikan

Rangkuti, Freddy. 2005. Analisis SWOT: Teknik Membedah Suatu Kasus. Jakarta: Gramedia.

Rifma. (2016) Optimalisasi Pembinaan Kompetensi Pedagogik Guru Dilengkapi Model Pembinaan Kompetensi Pedagogik Guru. Jakarta: Kencana.

Saifulloh Moh, Muhibbin Zainul, Hermanto. 2012. Strategi Peningkatan Mutu Pendidikan di Sekolah. Jurnal Sosial Humaniora. Volume 5 Nomor 2.

Schein, Edgar H. 2004. Organizational Culture and Leadership. San Fransisco : Third Edition, JosseyBass Publishers

Siagian, P Sondang. 2005. Manajemen Stratejik. Jakarta: Bumi Aksara.

Sugiyono. 2016. Metode Penelitian Kombinasi (Mixed Methods). Bandung : Alfabeta.

Surya, Mohammad, dkk. 2010. Landasan Pendidikan: Menjadi Guru Yang Baik. Bogor: Ghalia Indonesia

Suyanto, dan Asep Jihad.2013.Menjadi Guru Profesional, Strategi meningkatkan Kualifikasi dan Kualitas Guru di Era Global. Jakarta : Esensi Erlangga Group.

Tangkilisan, Hessel Nogi S. 2003. Manajemen Modern Untuk Sektor Public. Yogyakarta: Balairung \& Co. 